Article

\title{
How Social Entrepreneurs Affect Performance of Social Enterprises in Korea: The Mediating Effect of Innovativeness
}

\author{
Changhwan Shin \\ Department of Social Welfare, Social Science College, Kyungpook Nationl University, 41566 Daegu, Korea; \\ chshin@knu.ac.kr; Tel.: +82-53-950-7163
}

Received: 6 July 2018; Accepted: 25 July 2018; Published: 27 July 2018

\begin{abstract}
Schumpeter argued that entrepreneurship brings about creative destruction in capitalist economies. South Korea enacted the Social Enterprise Promotion Act in 2007 to promote corporate social enterprise. However, despite government support, social enterprises in Korea are not successful, especially in social and economic performance, which is defined as the social and economic value that social enterprises should pursue. A questionnaire survey was conducted among 100 social entrepreneurs, and the structural equation model was used as the research method. The results of the analysis are as follows. Openness and innovativeness have a positive direct impact on economic as well as social performance. In addition, openness and innovativeness play a mediating role not only in social performance, but also in economic performance. This paper suggests theoretical and policy implications based on the above analysis.
\end{abstract}

Keywords: social enterprises; social entrepreneurs; openness; innovativeness; social performance; economic performance

\section{Introduction}

In 2007, the Social Enterprises Promotion Act was enacted in Korea to promote social enterprises and generate a positive environment for them. The Korean government officially certifies social enterprises that fulfill certain criteria: have a certain organizational form (corporations, cooperatives, non-profit corporations, etc.); realize the social purpose (job offer, social service provision, community contribution, etc.) as the main purpose of the organization; pay more than $50 \%$ of the income from sales activities to labor cost of the employees for the, have a decision structure in which stakeholders participate; have a decision structure in which stakeholders participate; and provide institutional support such as tax relief and labor expenses support. Since the enactment of the law, various social enterprises have emerged and disappeared, raising questions about the performance or success of such enterprises. Despite the certification and financial support system, the financial viability of social enterprises is not guaranteed.

In this study, we focus on social entrepreneurs as one of the factors affecting the performance of social enterprises. In his seminal work, Schumpeter stated that capitalism evolves into a process of creative destruction through ongoing innovation, and that entrepreneurship brings about creative destruction [1]. Entrepreneurs are innovators who combine available resources in new ways. Social enterprises result from innovation aiming to solve emerging problems in capitalist societies, and social entrepreneurs play a key role in creating innovation, triggering creative destruction, and bringing about a positive change to solve social problems [2,3]. In this sense, social entrepreneurs hold the key to the success or failure of social enterprises. Therefore, this study focuses on social entrepreneurs. If it is difficult to ensure the performance of social enterprises through financial support alone, other factors will need to be considered for Korea's social enterprises. 
However, while the performance of social enterprises has received increasing attention in recent years, debate on the openness and innovativeness of social entrepreneurs is relatively limited. Open innovation is important for sustainable growth of social as well as business enterprises [4-10]. Many researchers have recently focused on open innovation in the business sector. According to Chesbrough, successful enterprises are innovative and open to the use of internal and external resources [4]. He argued that, whereas profitable business enterprises were based on closed innovation in the 20th century, successful enterprises of the 21st century are founded on open innovation. This is the so-called "paradigm shift". He also underscored that innovation requires an opening up business model and that the closed innovation model hardly succeeds in the 21st century economy [5]. Open innovation is a process realized at the firm level and that the theory of open innovation emphasizes a combination of new ideas and technologies adopted by a firm [8]. Open innovation is a key factor of the social as well as the business sector [10,11]. We consider openness and innovativeness as the characteristics of social entrepreneurs that affect sustainability, focusing on the performance of social enterprises. Concretely, examining the relationship between social entrepreneurship dimensions such as innovativeness and openness as well as the sustainability of social enterprises was the main theme of this research.

This study's research questions were as follows. How do social entrepreneurs affect the performance of social enterprises? How do the openness and innovativeness of social entrepreneurs affect social and economic performance?

To answer these research questions, self-reported questionnaires were administered to 100 top managers of Korea's government certified social enterprises. The survey measured four dimensions: openness, innovativeness, social performance, and economic performance. To illustrate the relationships among these variables, a path model was constructed using structural equation modeling. This study focuses on the mediating effect (indirect effect) of innovativeness, especially in relation to openness and sustainability.

This study identified the attributes of social entrepreneur to explain the performance of social enterprises. Thus, the study is expected to contribute to the theoretical discussion on the concept of social entrepreneur as well as to the research and debate on the viability of social enterprises, which are still limited. In addition, this study is expected to provide practical policy-making implications for the promotion and viability of social enterprises in terms of social and economic values.

\section{Literature Review}

\subsection{Social Entrepreneur}

\subsubsection{Social Entrepreneur and Social Entrepreneurship}

Social entrepreneurship is a primary and important factor in the performance of social enterprises. Many research studies on social entrepreneurship stress the behavior and characteristics of social entrepreneurs. According to Dees, "The entrepreneur always searches for change, responds to it (entrepreneurship), and exploits it as an opportunity" [12]. The concept of entrepreneurship has been defined and discussed since Schumpeter produced his seminal work on entrepreneurship. Entrepreneurship was the driving force of capitalist development and has been discussed as an important factor in overcoming the limitations of capitalism [4-7]. There is no generally accepted definition of "social" entrepreneurship. Although the concept and areas of social enterprise differ from country to country, social entrepreneurship is defined as entrepreneurship that embraces an approach to achieve social purpose and profit generation. Despite the important role of social entrepreneurs, there is no agreed definition on social entrepreneurship, as with the concept of social enterprise, and it has been defined in various ways [13]. "Social entrepreneurship is a much newer concept than commercial entrepreneurship and has been defined in many ways over the past few years" [14] (p. 4). On the other hand, some researchers use the terms business entrepreneurship and social entrepreneurship interchangeably [15]. Social entrepreneurship has also been considered 
as an extension of the entrepreneurial spirit of the commercial enterprise to the social domain [16]. However, commercial entrepreneurship and social entrepreneurship have distinct characteristics in terms of corporate mission, enterprise performance, and resource mobilization [17,18].

Some underscore the difference between the two concepts, while others note the similarities between them. The former pays attention to the differences between the two: the mission to pursue, the objectiveness of the enterprise, and motivation $[11,12,17,19]$. On the other hand, the latter focuses on the work process and communication in the organization, and the leadership of the entrepreneur [20,21]. The role of a social entrepreneur, as the leader of a hybrid organization pursuing social values and economic values at the same time, is important in that he manages and identifies social and economic values to be pursued under the pressure of conflict or contradiction. If an organization focuses on any one value especially economic performance, the organization loses its identity as a social enterprise [12,22-25], "Overemphasizing economic objectives may damage a social enterprise's legitimate status" [25]. The conceptual definition of social entrepreneurship differs according to the focus of researchers; however, it is clear that social entrepreneurship is distinct from commercial entrepreneurship as the latter focuses on the creation of profits. Social entrepreneurs are enthusiastic, and passionate, and aim to pursue a social mission, which reflects their innovative mind and behavior.

The social entrepreneur promotes innovation and improves the performance of social enterprises. The increasing importance of the behavior of social entrepreneurs in the performance of social enterprises, which reflects the underlying concept of social entrepreneurship, is considered an important factor for sustainable development of social enterprises [26]. It is essential for social entrepreneurs to secure the viability of social enterprises in an uncertain and dynamic environment, and the decisive factors that determine the sustainability of social enterprises are the characteristics, behaviors, and capabilities of social entrepreneurs [26,27].

Many researchers have attempted to define the characteristics of social entrepreneur. Social entrepreneurship has been identified with the nature of social entrepreneurs [24], personal leadership of social entrepreneurs [28-30], ethical awareness [27,31], and passion for realizing goals [24,27], and as an innovative way of tackling unmet socio-economic needs [19,32]. Social entrepreneurship, in a broad sense, is an innovative activity with a social purpose and is manifested through various aspects of social enterprises, such as commercial success, commercialization, corporate social entrepreneurial activities, and non-pursuit of profits $[15,17,31]$. In a narrow sense, it refers to a nonprofit organization that applies market-based business technology and focuses on creating social value rather than maximizing individual and shareholder interests.

Recently, researchers have focused on the behavioral characteristics of social entrepreneurs in explaining the characteristics of social entrepreneurship [14,21,23,26,27,33]. In particular, characteristics such as the development and maintenance of external resources and the exploration, recognition, and utilization of environmental opportunities are of more importance under uncertain environmental conditions and dynamics. The study on the constituents of social entrepreneurship mainly focuses on the behavioral characteristics of entrepreneurs [23,33-36]. Accordingly, the concept of social entrepreneurship has been defined in various ways; it is difficult to define social entrepreneurship as a single dimension. Weerawardena and Sullivan proposed the innovativeness, pro-activeness, and risk-taking behavior of entrepreneurs as components of social entrepreneurship and examined the behavioral characteristics of social entrepreneurs as social entrepreneurship [35]. Three dimensions of entrepreneurship were developed, which are mainly used for measuring the entrepreneurship of market-oriented firms (profit organizations). Most of the quantitative research on social entrepreneurship proceeds with multidimensional concepts.

\subsubsection{Innovativeness and Openness}

Many researchers emphasize that the only way to overcome the limits of capitalism as well as those of each business and social enterprise is to reinforce innovation and openness $[4,5,7,8]$. Several researchers present openness as a paradigm of innovation. Open innovation has become 
increasingly important practice and theory in recent years. Open innovation means generally openness in innovation [37]. The literature on open innovation defines open business model as contemporary tool that creates and captures value in collaboration with external partners [38].

Schumpeter, Drucker, Stevenson and many other scholars argued that entrepreneurs and entrepreneurship exist in the commercial, social, government sector and university [12]. "Entrepreneurs are who have a mind-set and a kind of behavior that can be manifest anywhere" [12] (p. 3). However, social entrepreneurs pursue social missions that are difficult to achieve and overcome challenges and obstacles. Therefore, many practitioners and theorists have emphasized "entrepreneurial" as a key element of social entrepreneurs, especially in comparison to commercial entrepreneurs. Ashoka suggested that social entrepreneurs are entrepreneurial, creative, and agenda-setting [18]. Leadbeater proposed that social entrepreneurs are more innovative than other entrepreneurs in that they find ways to satisfy unmet social needs by utilizing scarce resources [20]. Based on previous work, it could be concluded that social entrepreneurs are innovative. Social entrepreneurs should create economic and social values in their surroundings and portray social enterprises as organizations that exist to solve social problems [16-18,35]. Openness is necessary because social entrepreneurs need to interact with customers, stakeholders, the community/society, the local government, and so on. To solve the changing environment problems and to cope with resource constraints, the degree of openness is considered an important factor in innovation [4,37,39]. Openness is an especially important behavioral characteristic for social entrepreneurs. In sum, innovation performance is facilitated by the degree of openness.

In this sense, the impact of innovativeness on social value creation would depend on the degree of openness. "The success of social enterprises depends on the extent to which they strive to move towards open innovation. Adopting open innovation strategies seem to be a fruitful pathway for social enterprises to progress and grow in their operations" [6] (p. 1).

This research used "innovativeness" rather than "innovation" because the former refers to the behavioral characteristic of social entrepreneurs, whereas the latter is related to the activity and output (e.g., patent numbers) at the enterprise or organizational level. Further, this research was based on the premise that openness and innovativeness are distinct concepts. Considering that openness leads to innovativeness, this study assumes that the relationship between openness and innovativeness is temporal.

\subsection{Performance of Social Enterprises}

Social enterprises have special characteristics that fulfill both economic and social purposes at the same time. However, it is challenging for social enterprises to not only create social value, which is not generated by commercial enterprises, but also pursue an economic purpose with limited resources and support. Social enterprises endeavor to achieve social performance as well as financial sustainability by generating profits. A basic problem with research on this topic is how to define the concept of performance in the context of social enterprises.

In some cases, the performance of social enterprises is understood as an aspect of the sustainability of social enterprises [40,41]. In other cases, the financial performance of social enterprises is mainly identified as the sustainability of social enterprises [42]. The former researchers understood performance of social enterprises as delivering positive social and economic impacts to the community $[37,43]$, whereas the latter understood it as financial or economic viability that is commercially sustainable and used the term "sustainability". Some have defined sustainability in terms of both social performance and economic performance. To maintain a sustainable social enterprise, social entrepreneurs must fulfill their responsibility in economic and social aspects. Several studies analyzing the sustainability of social enterprises have defined sustainability as either social performance or economic (financial) performance, or both, and used various performance indicators to measure sustainability. Sustainability is defined as achieving economic viability and social impacts [44]. Many academic works mixed both these terms which are interchangeable in 
that the better the performance, the greater the sustainability. The performance of social enterprises depends on their ability to meet social expectations while meeting the needs of their consumers or users and making profits.

Some understand this concept from the perspective of social performance, such as the production of services and products that contribute to the community and the provision of services and programs to the underprivileged. From the economic perspective, social enterprises must generate revenue by providing products and services through commercial activities. Business activities should be pursued for the sustainability of social enterprises. "Social entrepreneurship generally works with market forces not against it" [14] (p. 4). Economic performance describes state in which revenues is generated and reinvested to fulfill social impact $[45,46]$.

Some empirical studies do not clarify whether the relationship between social and economic performance is positive or negative. The study of Miles et al. shows no significant correlation between the two $(r=0.181)$. However, according to some research, social enterprises that achieve social performance are expected to perform economically. Some empirical studies on the relationship between social and economic performance have suggested a meaningful positive relationship between the two. The attainment of social performance helps to improve economic profit [47-50].

Building on previous work, this study defined the performance of social enterprises as the creation of social performance and financial performance through social performance. In other words, for a social enterprise to be sustainable, its social performance should be linked to its economic performance in the long term $[40,50]$. These studies on the relationship between social and economic performance usually conclude that a positive relationship could be established, or at least that social performance does not negatively affect economic performance. In this study, we defined the performance of social enterprises as a state in which social performance leads to financial performance. This does not imply that economic performance is the ultimate and most important achievement of social enterprises. However, the social enterprises cannot financially survive without economic performance. Thus, performance does not just imply the attainment of social purpose; this attainment must move toward the creation of economic performance.

\subsection{Relationship between Social Entrepreneurs and Performance of Social Enterprise}

Previous studies have identified four main drivers of social enterprises economic and social performance. The first consists of personal factors: the leadership of social entrepreneurs, management competence, and attitude of business operation [27]. The second relates to the institutional factors: government financial support and institutional support [51]. The third includes organizational factors such as organizational structure, governance structure, organizational culture, leadership, cohesion, and organizational strategy [32,50,52]. Finally, performance is also driven by environmental factors such as network with stakeholders, social support, and government nonfinancial support $[53,54]$. The performance drivers of social enterprises are also related to each other. Organizational and environmental factors are important for social enterprises. However, considering social entrepreneurs decide the direction and strategy of the social enterprise and organize and control these factors, this study focused on social entrepreneurs, particularly their openness and innovativeness. The role of competent social entrepreneurs, who are open and innovative, is considered important for the promotion of social enterprises.

\section{Materials and Methods}

\subsection{Research Model}

This study examined the mediating effect of openness in that social enterprises should be open to speed up innovation and increase performance. In this study, we set up the following path model based on previous studies. The research model of this study is shown in Figures 1 and 2. 


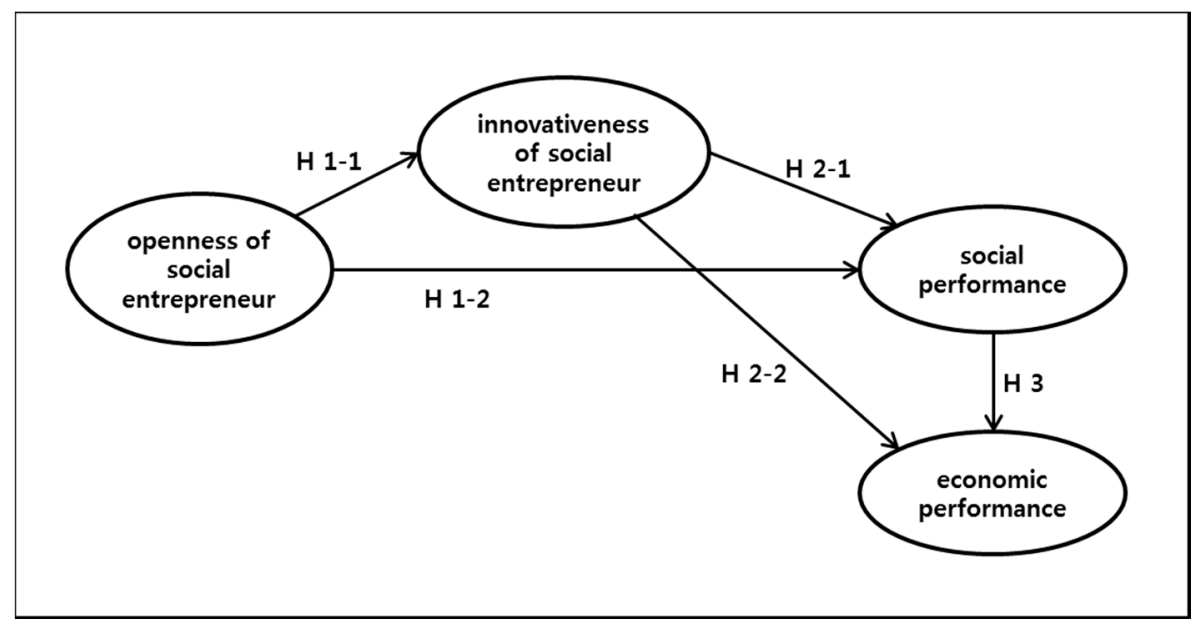

Figure 1. Research model (direct effect).

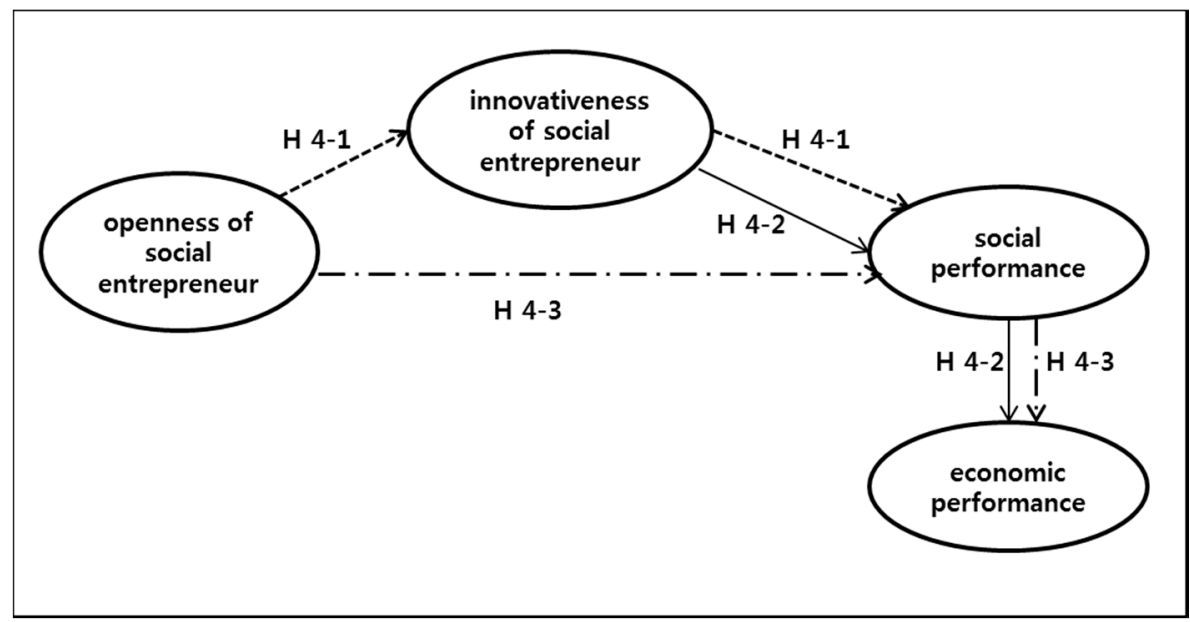

Figure 2. Research model (indirect effect).

The openness of social entrepreneurs affects their innovativeness of social entrepreneurs (Hypothesis 1-1), as well as social performance (Hypothesis 1-2). The innovativeness of social entrepreneurs affects social performance (Hypothesis 2-1) and economic performance (Hypothesis 2-2). Social performance affects economic performance (Hypothesis 3). Hypothesis 3 suggests that social performance is the primary goal of social enterprise. Conversely, economic performance is likely to affect social performance. As mentioned above, the social mission is the fundamental purpose of social enterprise, while profit making is secondary and just a means to a social end, not the end in itself [12]. We also examined whether the innovativeness of social entrepreneurs mediates their openness and social performance (Hypothesis 4-1), whether social performance mediates innovativeness and economic performance (Hypothesis 4-2), and whether social performance mediates openness and economic performance (Hypothesis 4-3). This study used structural equation modeling (SEM) to analyze the relationship between openness, innovativeness, and sustainability.

\subsection{Sample and Data Collection}

West et al., (2006) identified five levels of analysis in open innovation research: (1) individual and groups; (2) firm/organization; (3) inter-organizational value network; (4) industry and sector; and (5) national institutions and innovation system [55]. 
The social enterprises analyzed in this study are those registered on the website of Korea Social Enterprise Promotion Agency (www.socialenterprise.or.kr). As of March 2017, there were 435 companies reporting social enterprises' 2016 status information to the Korea Social Enterprise Promotion Agency. A survey was conducted among the top managers of these companies for three months from December 2017 to February 2018. A total of 100 out of 435 questionnaires were collected and the response rate was $23 \%$. A self-reporting questionnaire was used in this study based on previous surveys. Many research studies on social entrepreneurship and behavioral characteristics of social entrepreneurs have used self-reporting questionnaires [22,25,47,49,52].

\subsection{Measures}

\subsubsection{Dependent Variable}

The leading academic researchers on the performance of social enterprise, Miles et al., proposed the concepts of social and economic performance. The following are some questions on the social performance scale: our organization operates in a socially sustainable manner; we help inform the community about the plight of our beneficiaries; we are often perceived and valued by our beneficiaries as the providers of last resort; the beneficiaries are satisfied with our services. The economic performance scale is as follows: in the past few years, we have increased our effectiveness; in the past few years, our financial situation has improved; our organization is financially sustainable. Several stuides on the performance of social enterprises have measured the perception of social entrepreneurs in this way [22].

In this study, performance, which is a self-rated score, was measured on a seven-point Likert scale ranging from of 1 (very negative) to 7 (very positive). Social performance is defined as the degree to which a social enterprise creates value, such as community contribution, job creation, and social service provision. It was measured through five items: (1) our company receives favorable evaluation from local residents; (2) our company makes internal investment of revenues for employee pay increase or service/product R\&D; (3) our company makes external investments of revenues for community returns; (4) the employee of our company take pride in their work; and (5) our company contributes toward positive changes in our society.

Economic performance was defined in terms of financial viability, and it was measured through three items: (1) our company's sales is constantly increasing; (2) our company's operating profit is constantly increasing; and (3) our company's net profit is constantly increasing.

Cronbach's $\alpha$ is 0.893 for social performance and 0.855 for economic performance; the reliability of the two variables was secured.

\subsubsection{Independent Variable}

The independent variables included openness and innovativeness, both of which were self-rated traits, and were measured on a seven-point Likert scale ranging from 1 (very negative) to 7 (very positive). In this study, openness was defined as the efforts and activities of top managers to maintain their relationship with the external environment and uphold an open organization. Openness was measured by the level of communication with external experts, external organizations, and the stakeholders of social entrepreneurs, and so on.

Innovativeness focused on the behavioral characteristics of social entrepreneurs. Previous studies mainly used innovativeness and pro-activeness, as well as risk-taking, proposed by Weerawardena and Sullivan, as survey items [35]. In this study, innovativeness was measured by four items: to find innovative and creative business methods, to accept innovative ideas or business methods, to boldly support members' new ideas and technologies, and to improve the company's performance through creative change. Cronbach's $\alpha$ of openness is 0.921 for openness and 0.872 for innovativeness; the reliability of the two variables was secured. 


\section{Results}

\subsection{Descriptive Analysis and Correlation}

Table 1 shows the general descriptive characteristics of the social entrepreneurs who were surveyed. On average, those with no establishment experience and those with prior experience in the same field accounted for high proportions of the respondents.

Table 1. Descriptive statistics of respondents.

\begin{tabular}{cccc}
\hline Variable & Category & Frequency & Ratio \\
\hline \multirow{2}{*}{ start-up experience } & Yes & 29 & 29.9 \\
& No & 68 & 70.1 \\
\hline \multirow{2}{*}{ industry experience } & Yes & 54 & 55.1 \\
& No & 44 & 44.9 \\
\hline
\end{tabular}

Table 2 shows the descriptive statistics of key variables. Economic performance is lower than social performance, which implies that the social entrepreneurs surveyed in this study perceived lower financial performance in their own company.

Table 2. Descriptive statistics of key variables.

\begin{tabular}{ccc}
\hline Variable & Mean & Std. Dev. \\
\hline openness & 5.38 & 1.1471 \\
innovativeness & 5.42 & 1.1301 \\
social performance & 5.53 & 1.1081 \\
economic performance & 4.95 & 1.4225 \\
\hline
\end{tabular}

Table 3 presents the correlations between the main variables. The correlation coefficients between the variables are all statistically significant at the 0.01 level and show a positive relationship. However, the correlation coefficient between innovativeness and economic performance is lower than those of others. It is confirmed that there is no multi-collinearity.

Table 3. Correlation between variables.

\begin{tabular}{ccccc}
\hline & $\mathbf{1}$ & $\mathbf{2}$ & $\mathbf{3}$ & $\mathbf{4}$ \\
\hline Openness (1) & 1 & & & \\
Innovativeness (2) & $0.579^{* *}$ & 1 & & \\
Social performance (3) & $0.657^{* *}$ & $0.705^{* *}$ & 1 & \\
Economic performance (4) & $0.608^{* *}$ & $0.454^{* *}$ & $0.601^{* *}$ & 1 \\
\hline
\end{tabular}

** Significant at 0.01 level.

\subsection{Effects of Social Entrepreneurship on Sustainability}

\subsubsection{Direct Effect}

The analysis of the structural model is as follows. First, the model fit was obtained (Chi-square $\left(x^{2}\right)=134.968, \mathrm{DF}=85, \mathrm{CMIN} / \mathrm{DF}=1.588(p=0.000), \mathrm{RMSEA}=0.077, \mathrm{CFI}=0.954$, IFI = 0.946). The absolute fit index and relative fit index of the model were all secured. Therefore, it is possible to analyze the path coefficient of the structural model. Table 4 shows the effect of openness and innovativeness on social and economic performance. 
Table 4. Regression weights in the research model.

\begin{tabular}{cccccc}
\hline & Estimate & Beta & S. E & C. R & $p$ \\
\hline innovativeness $\longleftarrow$ openness & 0.589 & 0.640 & 0.120 & 40.929 & $* * *$ \\
social performance $\longleftarrow$ innovativeness & 0.340 & 0.290 & 0.121 & 20.820 & 0.005 \\
social performance $\longleftarrow$ openness & 0.541 & 0.615 & 0.128 & 40.228 & $* * *$ \\
economic performance $\longleftarrow$ innovativeness & 0.655 & 0.492 & 0.188 & 30.484 & $* * *$ \\
economic performance $\longleftarrow$ social performance & 0.390 & 0.297 & 0.712 & 20.267 & 0.023 \\
\hline
\end{tabular}

Figure 3 shows direct effect of each path between variables. Openness positively affects innovativeness and is statistically significant $(\beta=0.589, p=0.000)$. This implies that the more open a social enterprise is, the more innovative it is. Innovativeness positively affects social performance $(\beta=0.340, p=0.005)$. However, openness has a direct positive effect on social performance $(\beta=0.541$, $p=0.000)$. Innovativeness affects economic performance and is statistically significant $(\beta=0.655$, $p=0.000$ ). The standardized coefficients of the two paths (openness $\longrightarrow$ innovation: $\mathrm{B}=0.640$, openness $\longrightarrow$ social performance: $\mathrm{B}=0.615$ ) show that the openness coefficients are larger than those of the other paths. This means that openness is a key factor in innovation and performance improvement.

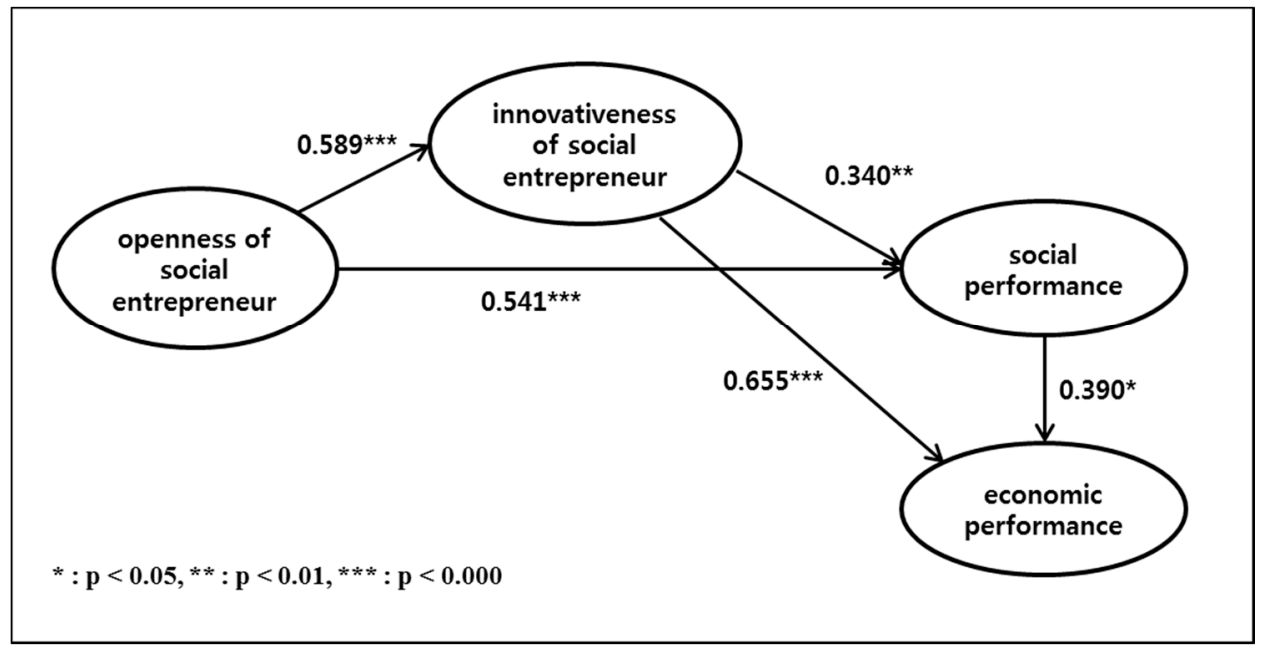

Figure 3. Path model (direct effect).

Openness is important because an open organization has high possibility of innovation and demonstrates high social performance. This analysis recognized the importance of innovation and demonstrated that innovative organizations demonstrate high social and financial performance. Open innovation fosters both social value and economic value, which are essential for the survival of social enterprises. Once again, we have confirmed the proposition that "openness drives innovation". Moreover, social performance has a directly positive effect on economic performance $(\beta=0.390$, $p=0.023)$. The results show that better social performance leads to better financial performance. The more the social enterprise creates social value, the higher the economic viability. In this way, all the paths set in the model have statistically significant meaningfulness, and thus, the hypotheses established in this study model are valid. Hypothesis 1-1, 1-2, 2-1, 2-2, and 3 were proven to be valid.

\subsubsection{Indirect Effect}

In this study, innovativeness and social performance were set to mediate openness. Innovativeness mediates openness and social performance, and social performance mediates innovativeness and economic performance. In the path model, openness affects innovation and 
innovativeness influences social performance. In other words, innovation is set to mediate openness and social performance. Openness also has an indirect effect on economic performance, although it has a direct impact on social performance. In other words, openness is set to mediate social performance and economic performance. Finally, innovativeness has a direct impact on social performance, but an indirect one on economic performance. In other words, innovation is set to mediate social performance and economic performance. A serial multiple mediator model is somewhat complicated, since there are various path models with causal relationships between mediator variables. The figure represents the indirect effect of three paths: (1) openness $(\mathrm{O}) \longrightarrow$ innovativeness $(\mathrm{I}) \longrightarrow$ social performance (SP); (2) openness $\longrightarrow$ social performance $\longrightarrow$ economic performance (EP); and (3) innovativeness $\longrightarrow$ social performance $\longrightarrow$ economic performance.

Table 5 shows the indirect effects of innovativeness, and social performance. Using bootstrapping, the statistical significance of the indirect effect of each mediator was verified. The indirect effect of openness on social performance through innovativeness is statistically significant (effect size $=0.200$; $p=0.008$ ). The indirect effect of openness on economic performance through social performance is statistically significant (effect size $=0.675 ; p=0.007$ ). This effect is higher than the other indirect effect. The indirect effect of innovativeness on economic performance through social performance is statistically significant (effect size $=0.133 . p=0.015$ ). As the bootstrapping method tests the indirect effect of variables, it captures the significance of mediating effect. Innovativeness shows a partial mediating effect between openness and social performance, and social performance shows a partial mediating effect between innovativeness and economic performance. However, social performance shows a complete mediating effect between openness and economic performance.

Table 5. Indirect effects (bootstrapping).

\begin{tabular}{cccccc}
\hline Effect & Estimate & Effect & Estimate & Effect & Estimate \\
\hline $\mathrm{O} \longrightarrow \mathrm{I}(\mathrm{a})$ & 0.589 & $\mathrm{O} \longrightarrow \mathrm{SP}(\mathrm{a})$ & 0.541 & $\mathrm{I} \longrightarrow \mathrm{SP}(\mathrm{a})$ & 0.340 \\
$\mathrm{I} \longrightarrow \mathrm{SP}(\mathrm{b})$ & 0.340 & $\mathrm{SP} \longrightarrow \mathrm{EP}(\mathrm{b})$ & 0.390 & $\mathrm{SP} \longrightarrow \mathrm{EP}(\mathrm{b})$ & 0.390 \\
$\mathrm{a}^{*} \mathrm{~b}$ & $0.200{ }^{* *}$ & $\mathrm{a}^{*} \mathrm{~b}$ & 0.211 & $\mathrm{a}{ }^{*} \mathrm{~b}$ & $0.1333^{*}$ \\
$\mathrm{O} \longrightarrow \mathrm{SP}\left(\mathrm{c}^{\prime}\right)$ & 0.541 & $\mathrm{O} \longrightarrow \mathrm{EP}\left(\mathrm{c}^{\prime}\right)$ & Not sig & $\mathrm{I} \longrightarrow \mathrm{EP}\left(\mathrm{c}^{\prime}\right)$ & 0.655 \\
Total $\left(\mathrm{c}^{\prime}+\mathrm{a}^{*} \mathrm{~b}\right)$ & 0.741 & Total $\left(\mathrm{c}^{\prime}+\mathrm{a}{ }^{*} \mathrm{~b}\right)$ & 0.211 & Total $\left(\mathrm{c}^{\prime}+\mathrm{a}{ }^{*} \mathrm{~b}\right)$ & 0.788 \\
\hline \multicolumn{5}{c}{$p<0.05,{ }^{* *} p<0.01($ two-tailed significance). }
\end{tabular}

The above results suggest that innovativeness and social performance play a key role in the economic viability of social enterprises. Although nnovativeness by itself directly increases sustainability of social enterprises, by playing a mediator role in improving social and economic performance, innovativeness intermittently raises the level of sustainability. Hypothesis 4-1, 4-2, and 4-3 were shown to be valid.

\section{Discussion}

This research provides several useful findings as follows. First, it demonstrates the importance of openness for innovation. An organization with a high degree of openness is more innovative. As Chesbrough emphasized, building a foundation of the open business model is an essential condition for the survival of modern corporate organizations [4]. This proposition applies to social enterprises as well. This study reconfirmed the importance of openness for innovation. Thus, openness is not an option but a necessity for the survival of social enterprises. Second, a social entrepreneur's innovativeness directly and indirectly increases social and economic performance of social enterprises. In other words, innovation has both direct and indirect effects on the performance of social enterprises. This implies that innovation is a key task not only for commercial enterprises but also for social enterprises. Third, the achievement of social purpose, which is the social enterprises' reason for existence, contributes to the creation of economic value. We define sustainability as the positive linkage 
between social performance and economic performance. As social and economic value creation is the essence of sustainability, open and innovative organizations tend to achieve sustainability.

In sum, openness leads to innovation and innovation leads to performance. Mere skill and technology acquisition do not enhance a new venture's innovation. The effect of openness, such as social network, plays a greater role in the innovation process $[53,54]$. Linking social performance to economic performance reinforces performance by social enterprises. The openness of social enterprises promotes social innovation in the short run and shapes the sustainability of social enterprises in the long run [40]. Innovation systems and innovative behaviors solidify and increase the sustainability of social enterprises [50,56,57].

Based on the above discussion, the theoretical and practical implications for social enterprises are as follows. First, this research theoretically provides a new path model that shows the effect of social entrepreneur on the performance of social enterprises. As an exploratory research, this study demonstrates the relationship between social entrepreneurs and social and economic performance, which is premised as a causal relationship and provides the theoretical basis for subsequent research. It is impossible to keep building business models without considering sustainability aspects $[10,11,14,15,20]$. Profitability is a necessity in social enterprises in the long as well as short run to create social value for the society, in which the social enterprise is located and provided with resources; thus, social enterprises should be innovative and open. To be sustainable, social enterprises must focus on the innovation system, which is supported by openness. Value creation and delivery, as well as value capture, are associated with sustainability. Value creation and delivery are linked to the key activities for the achievement of the mission/vision of the social enterprise, and value capture is linked with cost structures and revenue streams $[4,52,56]$. It is value creation and delivery that help social enterprises to achieve social performance. On the other hand, value capture means the formation of financial performance necessary for sustainability. Small and medium commercial enterprises should more actively adopt open innovation approaches for sustainability [9]. Social enterprises operate under similar conditions and are required to interact with external innovations, resources, and stakeholders.

Second, as a practical approach, we suggest education and training programs for social entrepreneurship. A social entrepreneur should have an open and innovative attitude. Thus, education and training programs need to be developed and executed institutionally with government support to foster these attitudes among social entrepreneurship aspirants and those facing difficulty in managing social enterprises. Existing discussions highlight the spirit of social entrepreneurs with an emphasis on innovativeness; however, this study confirmed that openness is also important. What is needed, therefore, is a policy that encourages social entrepreneurs to be more open and interactive with the environment surrounding the organization.

Openness and innovativeness are not only personal acts of social entrepreneurs, but they can also be improved through governmental support and efforts. Institutional support for social enterprises is needed for social entrepreneurship formation because the cultivation of social entrepreneurs fosters social enterprises. Cultivation of social entrepreneurs should be central to the training programs for social entrepreneurs. It is no exaggeration to say that the fostering and expansion of social enterprises lies in nurturing entrepreneurs with social entrepreneurship. Institutional support by the government is very important for the expansion of social enterprises that create positive externalities. Stephan et al. underscored that the government should play an active role in enhancing social entrepreneurship. Strong support for social entrepreneurship is an important requirement for the creation of social enterprises [51].

Third, to ensure the sustainability of social enterprises, the creation of social performance should lead to economic performance. Social enterprises in Korea are weak in many ways, particularly in terms of financial performance. This is supported by the fact that evaluation by the survey subjects is lower for financial performance than social performance. Indeed, many research studies related to Korean social enterprises point out financial vulnerability as a major problem. The role of intermediary 
support organization has been significant in the development of social enterprises in Korea [58]. Intermediary organizations of social enterprises should provide non-financial support such as consulting, mobilization of resources, network activation, and so on to establish linkages between social and economic performance.

This study has some limitations affecting the generalizability and validity. First, this study has small number of responses and self-report questionnaires were measured for Korean social entrepreneurs operating officially certified social enterprise. Second, this study focused on the behavioral characteristics of social entrepreneurs without reflecting all the factors affecting the performance of social enterprises in the research model. Therefore, it is necessary to consider these limitations in interpreting the results of this study. Notwithstanding these limitations, the findings provide some insights of social enterprise's performance and behavioral characteristics of social entrepreneur.

\section{Conclusions}

A social entrepreneur, as an important representative of the social enterprise, holds the key to organization's survival. This research identified the behavior of the social entrepreneur as one of the success factors. A social entrepreneur is expected to possess the qualities of openness and innovativeness, both of which are fostered by education and training. Korea's social enterprise support policy has so far focused mainly on external support such as tax relief and labor expenses support. Institutional support by the government is also needed to educate and train active social entrepreneurs; the promotion of social entrepreneurship eventually leads to the creation of social and economic value, which fosters the sustainability of social enterprises.

Acknowledgments: This work was supported by the Ministry of Education of the Republic of Korea and the National Research Foundation of Korea (NRF-2017S1A5A8022678).

Conflicts of Interest: The authors declare no conflict of interest.

\section{References}

1. Schumpeter, J. Creative destruction. Capital. Soc. Democr. 1942, 825, 82-85.

2. Svirina, A.; Zabbarova, A.; Oganisjana, K. Implementing open innovation concept in social business. J. Open Innov. 2016, 2, 20. [CrossRef]

3. Chesbrough, H.W. Open Innovation: The New Imperative for Creating and Profiting from Technology; Harvard Business Press: Boston, MA, USA, 2003.

4. Chesbrough, H. Open Business Models: How to Thrive in the New Innovation Landscape; Harvard Business Press: Boston, MA, USA, 2006.

5. Witt, U. What kind of innovations do we need to secure our future? J. Open Innov. 2016, 2, 17. [CrossRef]

6. Yun, J.J.; Park, K.; Im, C.; Shin, C.; Zhao, X. Dynamics of Social Enterprises-Shift from Social Innovation to Open Innovation. Sci. Technol. Soc. 2017, 22, 425-439. [CrossRef]

7. Yun, J.J.; Park, K.; Kim, J.; Yang, J. Open Innovation Effort, Entrepreneurship Orientation and their Synergies onto Innovation Performance in SMEs of Korea. Sci. Technol. Soc. 2016, 21, 366-390. [CrossRef]

8. Yoon, B.; Shin, J.; Lee, S. Open innovation projects in SMEs as an engine for sustainable growth. Sustainability 2016, 8, 146. [CrossRef]

9. Yun, J.; Won, D.; Park, K. Dynamics from open innovation to evolutionary change. J. Open Innov. $2016,2,7$. [CrossRef]

10. Schaltegger, S.; Wagner, M. Sustainable entrepreneurship and sustainability innovation: Categories and interactions. Bus. Strategy Environ. 2011, 20, 222-237. [CrossRef]

11. Shaw, E.; Carter, S. Social entrepreneurship: Theoretical antecedents and empirical analysis of entrepreneurial processes and outcomes. J. Small Bus. Enterp. Dev. 2007, 14, 418-434. [CrossRef]

12. Dees, J.G. The Meaning of Social Entrepreneurship; Duke University: Durham, NC, USA, 2001.

13. Brooks, A.C. Social Entrepreneurship: A Modern Approach to Social Value Creation; Pearson Prentice Hall: Upper Saddle River, NJ, USA, 2009. 
14. Drayton, W. The citizen sector: Becoming as entrepreneurial and competitive as business. Calif. Manag. Rev. 2002, 44, 120-132. [CrossRef]

15. Austin, J.; Stevenson, H.; Wei-Skillern, J. Social and commercial entrepreneurship: Same, different, or both? Entrepreneursh. Theory Pract. 2006, 30, 1-22. [CrossRef]

16. Mair, J.; Marti, I. Social entrepreneurship research: A source of explanation, prediction, and delight. J. World Bus. 2006, 41, 36-44. [CrossRef]

17. Drucker, P. Management Challenges for the 21st Century; Routledge: Abingdon, UK, 1999.

18. Ashoka Foundation. “Ashoka's Mission”. Available online: http:/ / ashoka.org.za (accessed on 25 July 2018).

19. Martin, R.L.; Osberg, S. Social entrepreneurship: The case for definition. Stanford Soc. Innov. Rev. 2007, 5, 29-39.

20. Leadbeater, C. Social Enterprise and Social Innovation: Strategies for the Next Ten Years; A Social Enterprise Think Piece for the Cabinet Office of the Third Sector; Cabinet Office of the Third Sector: London, UK, 2007.

21. Mulgan, G. The process of social innovation. Innovations 2006, 1, 145-162. [CrossRef]

22. Miles, M.P.; Verreynne, M.-L.; Luke, B. Social enterprises and the performance advantages of a Vincentian marketing orientation. J. Bus. Ethics 2014, 123, 549-556. [CrossRef]

23. Sullivan, M.G.; Weerawardena, J.; Carnegie, K. Social entrepreneurship: Towards conceptualisation. Int. J. Nonprofit Volunt. Sect. Mark. 2003, 8, 76-88. [CrossRef]

24. Dacin, P.A.; Dacin, M.T.; Matear, M. Social entrepreneurship: Why we don't need a new theory and how we move forward from here. Acad. Manag. Perspect. 2010, 24, 37-57.

25. Liu, G.; Eng, T.Y.; Takeda, S. An investigation of marketing capabilities and social enterprise performance in the UK and Japan. Entrepreneursh. Theory Pract. 2015, 39, 267-298. [CrossRef]

26. Bornstein, D.; Davis, S. Social Entrepreneurship: What Everyone Needs to Know; Oxford University Press: Oxford, UK, 2010.

27. Zheng, J.; Wu, G.; Xie, H. Impacts of Leadership on Project-Based Organizational Innovation Performance: The Mediator of Knowledge Sharing and Moderator of Social Capital. Sustainability 2017, 9, 1893. [CrossRef]

28. Thompson, J.; Alvy, G.; Lees, A. Social entrepreneurship-A new look at the people and the potential. Manag. Decis. 2000, 38, 328-338. [CrossRef]

29. Boschee, J. HOW TO MAKE TOUGH PRODUCT. Social entrepreneurs. Across Board 1995, 32, 20.

30. Prabhu, G.N. Social entrepreneurial leadership. Career Dev. Int. 1999, 4, 140-145. [CrossRef]

31. Henton, D.; Melville, J.; Walesh, K. The age of the civic entrepreneur: Restoring civil society and building economic community. Natl. Civ. Rev. 1997, 86, 149-156. [CrossRef]

32. Thompson, J.L. The world of the social entrepreneur. Int. J. Public Sect. Manag. 2002, 15, 412-431. [CrossRef]

33. Alvord, S.H.; Brown, L.D.; Letts, C.W. Social entrepreneurship and societal transformation: An exploratory study. J. Appl. Behav. Sci. 2004, 40, 260-282. [CrossRef]

34. Dees, J.G.; Anderson, B.B. For-profit social ventures. Int. J. Entrepreneursh. Educ. 2003, 2, 1-26.

35. Weerawardena, J.; Sullivan, M.G. Investigating social entrepreneurship: A multidimensional model. J. World Bus. 2006, 41, 21-35. [CrossRef]

36. Peredo, A.M.; McLean, M. Social entrepreneurship: A critical review of the concept. J. World Bus. 2006, 41, 56-65. [CrossRef]

37. Drechsler, W.; Natter, M. Understanding a firm's openness decisions in innovation. J. Bus. Res. 2012, 65, 438-445. [CrossRef]

38. Holm, A.B.; Günzel, F.; Ulhøi, J.P. Openness in innovation and business models: Lessons from the newspaper industry. Int. J. Technol. Manag. 2013, 61, 324-348. [CrossRef]

39. Carrillo, J.E.; Franza, R.M. Investing in product development and production capabilities: The crucial linkage between time-to-market and ramp-up time. Eur. J. Oper. Res. 2006, 171, 536-556. [CrossRef]

40. Moizer, J.; Tracey, P. Strategy making in social enterprise: The role of resource allocation and its effects on organizational sustainability. Syst. Res. Behav. Sci. 2010, 27, 252-266. [CrossRef]

41. Jenner, P. Social enterprise sustainability revisited: An international perspective. Soc. Enterp. J. 2016, 12, 42-60. [CrossRef]

42. Defourny, J.; Nyssens, M. Conceptions of social enterprise and social entrepreneurship in Europe and the United States: Convergences and divergences. J. Soc. Entrepreneursh. 2010, 1, 32-53. [CrossRef]

43. Galera, G.; Borzaga, C. Social enterprise: An international overview of its conceptual evolution and legal implementation. Soc. Enterp. J. 2009, 5, 210-228. [CrossRef] 
44. Mair, J.; Battilana, J.; Cardenas, J. Organizing for society: A typology of social entrepreneuring models. J. Bus. Ethics 2012, 111, 353-373. [CrossRef]

45. Harris, S.; Wheeler, C. Entrepreneurs' relationships for internationalization: Functions, origins and strategies. Int. Bus. Rev. 2005, 14, 187-207. [CrossRef]

46. Campbell, S. Social entrepreneurship: How to develop new social-purpose business ventures. Health Care Strateg. Manag. 1997, 16, 17-18.

47. Frumkin, P.; Andre-Clark, A. When missions, markets, and politics collide: Values and strategy in the nonprofit human services. Nonprofit Volunt. Sect. Q. 2000, 29, 141-163. [CrossRef]

48. Frumkin, P.; Kim, M.T. Strategic positioning and the financing of nonprofit organizations: Is efficiency rewarded in the contributions marketplace? Public Admin. Rev. 2001, 61, 266-275. [CrossRef]

49. Doherty, B.; Foster, G.; Meehan, J.; Mason, C. Management for Social Enterprise; Sage Publications: Thousand Oaks, CA, USA, 2009.

50. Moore, M.H. Managing for value: Organizational strategy in for-profit, nonprofit, and governmental organizations. Nonprofit Volunt. Sect. Q. 2000, 29, 183-204. [CrossRef]

51. Stephan, U.; Uhlaner, L.M.; Stride, C. Institutions and social entrepreneurship: The role of institutional voids, institutional support, and institutional configurations. J. Int. Bus. Stud. 2015, 46, 308-331. [CrossRef]

52. Voss, Z.G.; Voss, G.B. Exploring the impact of organizational values and strategic orientation on performance in not-for-profit professional theatre. Int. J. Arts Manag. 2000, 3, 62-76.

53. Shan, W.; Zhang, C.; Wang, J. Internal Social Network, Absorptive Capacity and Innovation: Evidence from New Ventures in China. Sustainability 2018, 10, 1094. [CrossRef]

54. Polese, F.; Botti, A.; Grimaldi, M.; Monda, A.; Vesci, M. Social Innovation in Smart Tourism Ecosystems: How Technology and Institutions Shape Sustainable Value Co-Creation. Sustainability 2018, 10, 140. [CrossRef]

55. West, J.; Vanhaverbeke, W.; Chesbrough, H. Open Innovation: Researching a New Paradigm; Oxford University Press on Demand: Oxford, UK, 2006; pp. 285-307.

56. Schlaile, M.; Urmetzer, S.; Blok, V.; Andersen, A.; Timmermans, J.; Mueller, M.; Fagerberg, J.; Pyka, A. Innovation Systems for Transformations towards Sustainability? Taking the Normative Dimension Seriously. Sustainability 2017, 9, 2253. [CrossRef]

57. Barth, H.; Ulvenblad, P.-O.; Ulvenblad, P. Towards a Conceptual Framework of Sustainable Business Model Innovation in the Agri-Food Sector: A Systematic Literature Review. Sustainability 2017, 9, 1620. [CrossRef]

58. Shim, S. Social Entrepreneurship: Concepts and Key Building Blocks; Korea Development Institute: Sejong-si, Korea, 2010.

(C) 2018 by the author. Licensee MDPI, Basel, Switzerland. This article is an open access article distributed under the terms and conditions of the Creative Commons Attribution (CC BY) license (http://creativecommons.org/licenses/by/4.0/). 